\title{
Observational Study of Blood Groups Distribution Among Medical Students in Central India
}

\author{
Ajay Kumar*, Sonu Ajmani and Priyanka Chouhan \\ Department of Physiology, Netaji Subhash Chandra Bose Medical college Jabalpur, M.P, India
}

\section{ABSTRACT}

Background: The ABO and Rhesus (Rh) blood group systems are clinically most important compare to other systems. Acquaintance of the geographical and ethnicity wise distribution of $\mathrm{ABO}$ and $\mathrm{Rh}$ blood group is necessary for operative management of blood banks, transfusion medicine and genetic research.

Aims: This Study was designed to collect data on $\mathrm{ABO}$ and Rh distribution among medical students who are natives of central India and its comparison with similar Indian studies.

Materials and Methods: Study was accomplished on 192 first and second year medical students belongs to central India (Madhya Pradesh) in the Department of Physiology NSCB Medical College Jabalpur, M.P. The blood samples were collected by finger prick method. ABO blood grouping and Rhesus factors (Rh) typing were decided by glass slide method.

Results: Among these medical students the maximum prevalent blood group was B (35.33\%) followed by O (34.95\%), A (21\%) and AB (08.72\%). Rh positive prevalence among these students was $96.32 \%$.

Conclusion: The study endorsed that blood group B is the commonest of the ABO blood group system in central Indian population and the $\mathrm{AB}$ blood group is the least. Rhesus positive is much commoner than Rhesus negative among them.

Keywords: ABO Blood Groups, Rh, central India, Medical Students.

\section{Introduction}

$\mathrm{ABO}$ and Rhesus (Rh) blood group systems till today remain clinically most important in spite of being identification of around twenty nine blood group systems, enumerated by International Society of Blood Transfusion. In 1900, Karl Landsteiner detected the human ABO blood group. ${ }^{1}$ The Rh blood group system was discovered during 1939-1940 by Landsteiner, Weiner, Levine and Stetson, clarifying the basis of many unpredicted transfusion reactions. In 1945, Coombs, Mourant and Race described the use of antihuman globulin (Coombs test) for incomplete antibodies. ${ }^{2}$ Later these two systems have substantiated to be the most important in transfusion medicine. Today, the requirement for blood group frequency and its prevalence is multiuse, besides their importance in relation to blood transfusion and organ transplantation. Blood group antigens can also be applied in genetic research, forensic pathology, anthropology and ancestral evolution of human. ${ }^{3}$

Nowadays, the ABO blood groups display an extensive geographical variation and vary noticeably, both within and among ethnic groups. Hence, the knowledge of blood group distribution in diverse population is for utmost importance in health care and transfusion practices. ${ }^{4}$
Knowledge of blood group distribution is vital for clinical studies as it provides information of dependable geographical region and it will aid a lot in genetic studies of such population. Knowledge of blood grouping provides access to safe supply of blood which will help significantly in reducing the preventable deaths. Therefore, it is relevant to have statistics on the frequency distribution of these blood groups in any population group.

\section{Material and Methods}

This cross sectional observational study conducted over students of central India at the Department of Physiology, NSCB Medical College, Jabalpur in the Period of January to March, 2016. The entire students included in the study group belong to Madhya Pradesh only. After prior informed consent and institutional ethical clearance samples were collected from one hundred ninety two medical students, studying first and second professional MBBS. All medical students, were from various areas of Madhya Pradesh i.e. belongs to regions of Indore, Gwalior, Bhopal, Rewa, Jabalpur, Chindwara, Balaghat and Shadol. The students in the same batches which were from other states of India were excluded from this study. Under a septic preventive 
measure by finger prick method non haemolysed blood samples were collected, and non-greasy glass slides was used for identification of $\mathrm{ABO}$ blood grouping and Rhesus factors $(\mathrm{Rh})$ typing. Commercially available Tulip diagnostics Eryscreen anti sera A, anti sera B and anti sera D kits were used for this study. Blood samples were treated with anti-A, anti-B and anti-D anti sera over glass slides and mixed uniformly over an area of $2.5 \mathrm{~cm}$ by mixing stick. After two minutes of gentle rocking samples were observed for agglutination, both macroscopically and microscopically. ${ }^{5}$

Following Landsteiner laws blood groups and IgG antibodies of $\mathrm{Rh}$ system of those students who were identified and their relevant data was entered into Microsoft Excel sheet 2013 and tabulated with graphical representation.

\section{Results}

Out of 192 medical students $132(68.75 \%)$ were males and $60(31.25) \%$ were females with mean \pm SD age of $19.95 \pm 0.85$ years. In our study, among all students most prevalent blood group was B, 70 cases $(35.33 \%)$ followed by $\mathrm{O}$ in 66 cases $(34.95 \%), \mathrm{A}$ in $41(21 \%)$ cases and $\mathrm{AB}$ in 15 cases $(08.72 \%)$.

Among 192 students 187 (97.39\%) showed Rh positive blood group. In Rh-positive cases, among boys AB and $\mathrm{O}$ blood group all were $\mathrm{Rh}$ positive, while in girls $\mathrm{A}$ and $\mathrm{O}$ blood groups were $\mathrm{Rh}$ positive. Among these students only 3 males and 2 females having Rh negative blood group.

It was also seen that blood group B was more prevalent among Muslims followed by O. All Muslim students showed Rh positive blood group

Table 1: Frequency distribution of different blood groups among medical students.

\begin{tabular}{|c|c|c|c|c|c|c|c|}
\hline $\begin{array}{c}\text { Blood } \\
\text { groups }\end{array}$ & Male (n=132) & Rh pos & Rh neg & Female (n=60) & Rh pos & Rh neg & Total \\
\hline A & 28 & 27 & 1 & 13 & 13 & 0 & 41 \\
\hline B & 48 & 46 & 2 & 22 & 21 & 1 & 70 \\
\hline AB & 11 & 11 & 0 & 04 & 3 & 1 & 15 \\
\hline O & 45 & 45 & 0 & 21 & 21 & 0 & 66 \\
\hline
\end{tabular}

Table 2: Frequency distribution of different blood groups among Muslim medical students.

\begin{tabular}{|c|c|c|c|c|}
\hline Blood groups & Total no $(\mathrm{n}=18)$ & Percentage & Male & Female \\
\hline A & 2 & 11.11 & 5 & 3 \\
\hline B & 8 & 44.44 & 2 & 0 \\
\hline AB & 2 & 11.11 & 3 & 3 \\
\hline O & 6 & 33.34 & 2 & \\
\hline
\end{tabular}

\section{Discussion}

Variables in $\mathrm{ABO}$ and $\mathrm{Rh} \mathrm{D}$ phenotypes are noted broadly across races and geographical boundaries. ${ }^{6}$ Limited studies on the prevalence of $\mathrm{ABO}$ and $\mathrm{Rh}$ blood groups have been conducted in the Indian population and common studies are limited to particular regions of the country. Very few such studies have yet been reported from central India.

In India, we have many types of ultra-rare phenotypes of blood groups like Bombay (Oh), -D -/-D-, In (a+b-), Colton-null phenotype, $\mathrm{CdE} / \mathrm{CdE}$ (ryry) phenotypes; those phenotypes are potential enough to pose problems in providing blood to the recipients having these phenotypes. ${ }^{7}$

The present study revealed among medical students of central India having prevalence of blood group $\mathrm{B}>\mathrm{O}>\mathrm{A}>\mathrm{AB}$. A study conducted by Talukdar et al, outside the State in Guwahati revealed blood group $\mathrm{O}$ was the commonest at $37.23 \%$ followed by blood groups B at $31.0 \%$, A at $24.83 \%$ and $\mathrm{AB}$ at $6.93 \%{ }^{8}$

Studies done in Northern parts of India by Chandra et al at Lucknow and Sindhu et al at Punjab showed blood group B was the commonest, followed by $\mathrm{O}, \mathrm{A}$ and $\mathrm{AB}$ which have similar finding as seen in our study. In western Ahmedabad, Patel et al carried a hospital based study predominantly among male donors and reported the commonest $\mathrm{ABO}$ blood was B (39.40\%) followed by O (30.79\%), A (21.94 $\%)$ and $\mathrm{AB}(7.86 \%)$. In this present study among student similar findings were seen with $\mathrm{B}$ as most prevalent (35.33\%) blood group followed by O (34.95\%), A (21\%) and $\mathrm{AB}(08.72 \%)$. A study done in Durgapur of West Bengal by Nag et al found that commonest blood group was O followed by B, A and AB, different from our study. ${ }^{9,10,11,12}$

The present study pointed that blood group $\mathrm{B}$ and $\mathrm{O}$ were also common in distribution among the female study group 
followed by the A and AB. Study done in North India by Chandra et al displayed among female blood donors the $\mathrm{B}$ positive blood group was most prevalent. ${ }^{9}$

A study carried on the distribution of blood groups among south Indian medical students of the Great Eastern Medical School, Andhra Pradesh by Swamy et al showed O was the commonest blood group in both sexes, but in this study among male students the commonest blood group was A and female students the maximum prevalent blood groups were $\mathrm{A}$ and B. ${ }^{13}$

The Rhesus blood group is the most polymorphic and its medical implication in transfusion medicine is only next to the ABO blood group system. Multicentric study in India by Agrawal et al revealed $94.61 \%$ of the donor population was $\mathrm{Rh}$ positive and the rest were $\mathrm{Rh}$ negative, similar to present study where $97.39 \%$ students were $\mathrm{Rh}$ positive and rest $2.61 \%$ were $\mathrm{Rh}$ negative. Study conducted by Parmanik et al over Nepalese medical students, in Nepal medical college, Kathmandu exhibited $96.66 \%$ Rh positive cases which was consistent finding with our study. ${ }^{14,15}$

A study conducted by Hussain et al among North Indian Muslim population highlighted the most frequent blood group was found to be group O $29.97 \%$ followed by A $26.52 \%$, B 20.03\% and AB 19.34\% ${ }^{16}$.

An epidemiological study in relation to Muslim and Christian communities of Kheda, Gujarat by Pant et al showed Blood group B was dominant in both the communities, having similar to our present study which shows that in medical students both $\mathrm{B}$ and $\mathrm{O}$ blood group were prevalent. ${ }^{17}$

A study done over 152 medical students in Davangere, Karnataka by Hemlatha et al published the most common blood group was O (41.5\%) followed by B group (32.2\%), A group (19\%) and least being AB group (7.2\% ). Among the $\mathrm{Rh}$ blood group, 94\% students were $\mathrm{Rh}$ positive, however only $6 \%$ were $\mathrm{Rh}$ negative. In this study among all one hundred medical students $\mathrm{A}, \mathrm{B}$ and $\mathrm{O}$ blood groups were seen in equal proportion, each in $30 \%$ cases and least being $\mathrm{AB}$ group (10\%) and Ninety seven percentage students were Rh positive. ${ }^{18}$

\section{Conclusion}

We noted that $\mathrm{ABO}$ and Rhesus ' $\mathrm{D}$ ' blood group distribution diverged in different parts of India. The study highlights similar frequency of distribution of $\mathrm{A}, \mathrm{B}$ and $\mathrm{O}$ blood group among students and B is the most prevalent blood group among central Indian population. Rhesus positive is much more common than Rhesus negative among this population as well as in respect to Indian population.
The knowledge of blood group distribution is important for clinical studies, for reliable geographical information and blood bank management. This study would help in developing India-specific reagent cell-panels for antibody screening and identification, which would further aid in the improvement of transfusion services in the country.

\section{Acknowledgements}

P. K Budholia, Ajay Mishra, G.D Mehra

\section{References}

1. Garratty G, Dzik W, Issitt PD, Lublin DM, Reid ME, Zelinski T. Terminology for blood group antigens and geneshistorical origins and guidelines in the new millennium. Transfusion. 2000;40(4):477-89.

2. Hillyer CD. Blood Banking and Transfusion Medicine - History, Industry, and Discipline. In: Shaz BH (ed.) Transfusion Medicine and Hemostasis. Amsterdam: Elsevier; 2013. p. 3-9.

3. Khurshid B, Naz M, Hassan M, Mabood SF. Frequency of $\mathrm{ABO}$ and $\mathrm{Rh}(\mathrm{D})$ blood groups in district Swabi N.W.F.P (Pakistan). J Sci Tech University Peshawar 1992;16:5-6.

4. Dar NJ, Srivastava A, Dar FA. Distribution of ABO blood groups and $\mathrm{Rh}(\mathrm{D})$ factor among the Brahmin and Kushwaha populations of Jhansi District UP. Nature Precedings.2011; hdl:10:1038/npre.6362.1.

5. "Racial and Ethnic Distribution of ABO Blood Types bloodbook.com, Blood information for life," 2006. http:// www.bloodbook.com

6. Makroo RN. ABO blood group system. In: Makroo BN (ed.) Compendium of transfusion medicine. New Delhi: Kongposh Publications Pvt Ltd; 2009.p.42.

7. Joshi SR, Vasantha K.A profile of rare bloods in India and its impact in blood transfusion service. Asian J Transfus Sci $2012 ; 6(1): 42-3$.

8. Talukdar L, Sarma U. Frequency of Major Blood Group Antigens among Blood Donors at a Tertiary Level Hospital in North East India. IJSR 2014;3(9):2130-2.

9. Tulika C, GuptaA. Frequency of $\mathrm{ABO}$ and Rhesus blood groups in blood donors. Asian J Transfus Sci 2012;6(1):52-3.

10. Sidhu S. Distribution of the ABO blood groups and $\mathrm{Rh}(\mathrm{D})$ factor among the scheduled caste population of Punjab. Anthropologist2003;5:203-4.

11. A Patel Pyush, Patel Sangeeta P, V Shah Jigesh, V OzaHaren. Frequency and Distribution of Blood Groups in Blood Donors in Western Ahmedabad - A Hospital Based Study. Nat 1 J Med Res 2012;2(2):202-206.

12. Nag I, Das SS. ABO and Rhesus blood groups in potential blood donars at Durgapur Steel City of the district of Burdwan, West Bengal. Asian J Transfus Sci 2012;6(1):54-5.

13. Swamy GG, Chandrasekhar B, Parameswari J, Madhuravani S.Frequency and distribution of blood groups among medical students of Great Eastern Medical School, Srikakulam, Andhra Pradesh, India. Int J Med Pharm Sci 2013;3(9):26-33.

e-ISSN: 2349-6991; p-ISSN: 2455-0396 
14. Agrawal A, Tiwari AK, Mehta N, Bhattacharya P, Wankhede $\mathrm{R}$, Tulsiani $\mathrm{S}$, et al. $\mathrm{ABO}$ and $\mathrm{Rh}(\mathrm{D})$ group distribution and gene frequency; the first multicentric study in India. Asian J Transfus Sci 2014;8:121-5.

15. Parmanik T, Parmanik S. Distribution of ABO and Rh blood groups in Nepalese medical students: a report. East Mediterr Health J 2000;6(1):156-8.

16. Hussain R, Fareed M, Shah A, Afzal M. Prevalence and gene frequencies of $\mathrm{A} 1 \mathrm{~A} 2 \mathrm{BO}$ and $\mathrm{Rh}(\mathrm{D})$ blood group alleles among some Muslim populationsof North India. The Egyptian Journal of Medical Human Genetics 2013;14:69-76.

17. Pant CS, Gupta DK, Sharma RC, Gautam AS, Bhatt RM.Frequency of ABO blood groups, sickle-cell haemoglobin, G-6-PD deficiency and their relation with malaria in scheduled castes and scheduled tribes of Kheda District, Gujarat. Indian J Malariol 1992;29(4):235-9.

18. Hemalatha N R, Bhagya V, Frequency and Distribution of Blood Groups Among Medical Students in Davanagere. J Pub Health Med Res, 2015;3(1):1-4.

*Corresponding author:

Dr Ajay Kumar, House no 14 Sai colony Dhanwantri Nagar Jabalpur M.P 482003 India

Phone: +91 9516639699

Email: acalculia007@gmail.com 